\title{
Nyttig med røntgen på sykehjem
}

«Hvorfor skal denne eldre pasienten sendes til røntgen - det vil jo ikke bli snakk om noen operasjon!» Som sykehjemslege kan det være tungt å bli møtt med manglende forståelse fra vakthavende sykehuslege (1). Hvor mye skal man presse på for å få tatt røntgen thorax hos eldre beboere med fast plass på sykehjem dersom det er mistanke om lungebetennelse? Det avgjørende er selvfølgelig om det vil få behandlingsmessige konsekvenser. Einar Vigeland og medarbeidere viser i sin artikkel i dette nummer av Tidsskriftet at i overkant av $80 \%$ av de mobile røntgenundersøkelsene faktisk fikk betydning for den videre behandlingen (2).

Ifølge forfatterne har mobile røntgentjenester på sykehjem betydning for både diagnose og behandling. Samtidig kan det være kostnadsbesparende for samfunnet. I ni av ti tilfeller kunne den mobile røntgenundersøkelsen bidra med viktig informasjon til pasienten og de pårørende. Men er denne informasjonen egentlig nødvendig når utfallet av undersøkelsen ender med at sykehuslegen innstiller på konservativ behandling, for eksempel av et udislosert brudd? Ja, fordi informasjonen kan redusere den diagnostiske tvilen og bidra i planleggingen av den videre behandling, selv om denne «kun» innebærer smertestillende medisiner og fysioterapi.

Fysisk aktivitet er god medisin for eldre - men som lege eller fysioterapeut må man sørge for at tilstander som ribbensbrudd, innkilte hoftefrakturer eller vertebrale skader ikke forblir uoppdaget (3). Over 200 eldre pasienter i sykehjem i Vestfold ville ikke fått røntgenundersøkelse dersom de hadde måttet sendes til sykehus (2). Dette viser at det bør etableres flere mobile røntgentjenester i Norge, spesielt der det er lang transportvei fra sykehjem til sykehus. Fra den aktuelle studien kan man derimot ikke konkludere med at bruken av mobil røntgentjeneste reduserer antallet unødvendige sykehusinnleggelser. En slik kostnad-nytte-analyse ville kunne belyse i hvilke landsdeler tilbudet burde prioriteres. Mobile røntgentjenester finnes foreløpig i Oslo og deler av Akershus, i Buskerud, Østfold, Vestfold og i Bergen.

I undersøkelsen ble kun en tredel av pasientene vurdert til å være mentalt friske. Det vil si at et de fleste var rammet av demens, kognitiv svikt eller alvorlig psykiatrisk lidelse. Dette stemmer godt med andre norske sykehjemsrapporter, der man har funnet at opp mot $80 \%$ av beboerne har en demensdiagnose (4). Disse pasientene er ofte ikke i stand til å redegjøre for hva som førte til at de for eksempel blir funnet liggende på gulvet på rommet sitt, noe som ofte skjer i sykehjem (5). Mangel på god kommunikasjon med pasienten gjør det vanskelig å vite hvor akutt og alvorlig hendelsen er. Sannsynligvis er det for denne pasientgruppen at mobile røntgentjenester kan gjøre størst nytte.

Mange med demens forstår ikke hensikten med å ta et røntgenbilde. I verste fall kan de under protest bli sendt til sykehus av sykehjemslegen for det som anses som en nødvendig røntgenundersøkelse. På grunn av redusert sykdomsinnsikt kan de sette seg imot dette undersøkelse og transport kan dermed oppleves som et overgrep. Pasienter med demens er også mer utsatt for å få delir ved forflyt- ning i ambulanse til sykehus (6). Når en radiograf reiser ut til sykehjemmet, tar røntgenbilder på stedet og kort tid senere får dem tolket av en radiolog på sykehuset, kan eventuelle brudd utelukkes. Dette vil tjene både sykehjem og sykehus. Derfor kunne fordelene med bruk av mobile røntgentjenester for sykehjemspasienter med demens og kognitiv svikt vært løftet enda mer frem i Vigeland og medarbeideres artikkel.

I bruken av mobile røntgentjenester er det viktig at sykehjemslegen kjenner pasientens habituelle tilstand for å ikke overse nytilkomne alvorlige tilstander som krever sykehusinnleggelse og CT-, MReller ultralydundersøkelse (7). Nytten for legevaktleger og legevikarer vil derfor være liten.

Helsemyndighetene må vurdere behovet for mobile røntgentjenester på sykehjem på nasjonalt plan. Her - som ved alt annet innen eldreomsorgen - er det økonomien som avgjør om tilbudet skal bli landsdekkende. Og skal første- eller annenlinjetjenesten sitte med ansvaret for å bygge ut tilbudet? Sykehjemsleger vil dra nytte av den diagnostiske hjelpen fra røntgenbildene, og at samfunnet sparer kostnader ved at pasienter ikke sendes unødig til sykehus er opplagt. Dessuten har svenske kolleger nylig vist at det kan gi mindre angst hos pasientene (8). Spørsmålet er altså ikke om mobile røntgentjenester er et nyttig tilbud til sykehjemspasienter, spørmålet er hvem som skal ta regningen - kommunen eller spesialisthelsetjenesten?

\section{Tor Atle Rosness}

tor.rosness@tidsskriftet.no

Tor Atle Rosness (f. 1976) er medisinsk redaktør i Tidsskriftet, sykehjemslege i Bærum kommune og førsteamanuensis ved Lovisenberg diakonale høgskole.

\section{Litteratur}

1. Rosness TA. De ensomme legene. Tidsskr Nor Legeforen 2016; 136: 103

2. Vigeland E, Bøhm R, Rostad A et al. Mobil røntgentjeneste ved sykehjem. Tidsskr Nor Legeforen 2017; 137: 198-202.

3. Helbostad JL. Fysisk trening av sykehjemsbeboere - har det noen hensikt? Tidsskr Nor Lægeforen 2005; 125: 1195-7.

4. Selbæk G. Demens - behov for et kvalitetsløft. Tidsskr Nor Lægeforen 2006 ; 126: 1892

5. Ranhoff $\mathrm{AH}$, Linnsund JM. Når skal sykehjemspasienter innlegges i sykehus? Tidsskr Nor Lægeforen 2005; 125: 1844-7

6. Bruserud $\emptyset$. Best behandling i sykehjem. Tidsskr Nor Legeforen 2015; 135: 18.

7. Graverholt B, Riise T, Jamtvedt $\mathrm{G}$ et al. Acute hospital admissions among nursing home residents: a population-based observational study. BMC Health Serv Res 2011; 11: 126.

8. Dozet $A$, Ivarsson $B$, Eklund $\mathrm{K}$ et al. Radiography on wheels arrives to nursing homes - an economic assessment of a new health care technology in southern Sweden. J Eval Clin Pract 2016; 22: $990-7$. 